\title{
Genetic variation in testicular development in mice of the C57BL/10ScSn, C57BL/6By and BALB/cBy strains and the CXB recombinant-inbred lines*
}

\author{
N. M. Shukri and J. G. M. Shire \\ Department of Biology, University of Essex, Colchester CO4 3SQ, Essex, UK
}

\begin{abstract}
Summary. When compared with C57BL/6By mice, BALB/cBy mice had testes that were $41 \%$ heavier at 60 days of age and seminiferous tubules that were $41 \%$ greater in cross-sectional area at 120 days. Absolute testicular weight did not increase between 60 and 120 days of age in either $\mathrm{C} 57 \mathrm{BL} / 6 \mathrm{By}$ or $\mathrm{C} 57 \mathrm{BL} / 10 \mathrm{ScSn}$ mice but did in BALB mice, paralleling changes in the size of the seminiferous tubules. Significant testicular growth took place over this age period in mice of all seven of the CXB recombinantinbred (RI) strains of mice derived from a cross of the BALB/cBy and C57BL/6By strains. The wide range of phenotypes shown by adult recombinant mice, which ranged from those with significantly heavier testes than BALB to those with testes the same size (at 60 days) as those of $\mathrm{C} 57 \mathrm{BL} / 10 \mathrm{ScSn}$ mice, implied the existence of several separable factors affecting testicular size in adults. At 30 days of age the RI lines fell into two groups; one with small testes like $\mathrm{C} 57 \mathrm{BL} / 6 \mathrm{By}$ and the other with larger testes like BALB/cBy mice. The segregation pattern for prepubertal testicular weight was identical to that for the $H$-2 histocompatibility locus.
\end{abstract}

Keywords: mouse; testes; seminiferous tubules; histocompatibility; $H$-2 locus; growth

\section{Introduction}

Significant genetic differences affecting the reproductive function of normal adults have been demonstrated for laboratory and farm species (reviewed by Bartke, 1979; Land \& Carr, 1979; Shire, 1981; Diamond, 1986). There have been relatively few attempts to determine when in development such differences appear and even fewer that ask whether the pattern of expressed genetic differences remains constant during development. Any changes in the sets of gene-loci active during development will be reflected in changes with age in the direction or nature of phenotypic differences between animals of the same species but of different genotypes.

Prenatal differences between mice of different inbred strains have been described for gonadal size in males (Hunt \& Mittwoch, 1987) and for fetuses of both sexes (Argyropoulos \& Shire, 1989), while several significant differences between adult mice have been described (Shire \& Bartke, 1972; Hayward \& Shire, 1974; Islam et al., 1976; West et al., 1980; Wolfe et al., 1981; Stalvey \& Payne, 1983; Osadchuk \& Naumenko, 1983; Stewart, 1983). This study complements the prenatal analysis of Argyropoulos \& Shire (1989) by following the postnatal development of the gonads in males of the C57BL/6By and BALB/cBy strains that they studied. The strains were chosen for two reasons; because of their known phenotypes and because of the availability of special genetic stocks derived from them. Mice of the BALB/c strain have large testes and are responsive to androgens (Shire \& Bartke, 1972; Batty, 1978; Paigen, 1978) whilst mice of several sublines of the C57BL strain have low blood androgen concentrations are relatively insensitive to exogenous testosterone and have

*Reprint requests to: J. G. M. Shire. 
relatively low levels of male sexual and aggressive behaviour (Bartke, 1974; Batty, 1978; Paigen, 1978; Maxson, 1981; Stewart, 1983). The C57BL/6By and BALB/cBy sublines were chosen because of the set of CXB recombinant-inbred lines that had been derived from an F2 cross between them (Bailey, 1971). Gonadal development cannot be followed over time within a single animal but requires replicated observations of animals of the same genotype at different ages. This is possible for mice from homozygous inbred strains, as all members of a particular strain have identical genotypes. However, each individual in a segregating F2 or backcross generation has a unique genotype and cannot be pooled with others for analyses of developmental characters. The use of recombinant-inbred (RI) strains allows the analysis of the segregation patterns of such characters. Each RI strain represents an individual F2 haplotype made homozygous by inbreeding and thus available for measurements of developmental traits. Such measurements enable the developmental, physiological and genetic relationships between characters that differ between the progenitor strains to be analysed. The CXB set of RI strains has been used to analyse variation in female reproductive characters (Eleftheriou \& Kristal, 1974; Shire \& Whitten, 1980; Shire, 1984; Bander et al., 1988).

This paper describes the postnatal development of testis weight in C57BL/6By, BALB/cBy and the seven CXB RI strains. Parallel measurements were made on C57BL/10ScSn males, chosen to represent the other main group of sublines of C57BL (Festing, 1979). Measurements were made at the ages of 30 days (before puberty), 60 days (sexually mature) and 120 days (full adulthood).

\section{Materials and Methods}

Mice. Mice from the BALB/cByEss, C57BL/6ByEss and C57BL/10ScSnEss inbred strains were studied, together with the seven CXB recombinant-inbred strains (CXBD, CXBE, CXBG, CXBH, CXBI, CXBJ, and CXBK) derived by Bailey (1971) from crosses between BALB/cBy and C57BL/6By. All mice were bred and raised at the University of Essex under standard environmental conditions (Shukri et al., 1988).

Tissue sampling. Mice were killed with halothane at the ages of 30,60 and 120 days. They were weighed and then the testes were removed and weighed. Testes from two males from each of 4 litters of the BALB/cBy and C57BL/6By strains were rapidly frozen and $12 \mu \mathrm{m}$ thick sections cut with a cryostat. Sections were stained by the method of Wiebe (1976) and the dimensions of the seminiferous tubules were determined with a measuring projection microscope (Dynascope, Vision Engineering Ltd, Denley, Surrey, UK), using a $\times 10$ magnification objective. The long $(x)$ and short $(y)$ diameters of cross-sections of the tubules were measured and the cross-sectional area calculated by applying the formula for the area of an ellipse. The areas of 5 seminiferous tubules were measured for each section, and 2 sections were measured for each testis. The distribution of counts within and between sections was chosen following the suggestions of Fahle \& Palm (1983).

Statistical analysis. One-way analysis of variance was used to assess the significance of the observations within each age group, using the SPSS statistical package (Nie et al., 1975). The least significant difference (LSD) test was used for comparisons between means of different genotypes at the same age. Correlation analysis was used to determine the closeness of the relationship between testicular weights at the different ages and between testicular weight and bodyweight. The cross-sectional areas of the seminiferous tubules were analysed with a two-way ANOVA. A probability level of 0.01 was used throughout as the criterion for significant differences, because of the large number of comparisons made.

\section{Results}

The numbers of mice analysed at the ages of 30,60 and 120 days and their bodyweights are shown in Table 1. The overall patterns of growth of the two C57BL sublines were similar, with mice of both strains increasing in weight by 6-7 $\mathrm{g}$ between the ages of 60 and 120 days. The two progenitor strains (C57BL/6By and BALB/cBy) and the seven CXB RI lines derived from them showed only small differences in bodyweight. The largest and smallest mean values at 120 days differed by only $14 \%$. Analysis of variance did, however, show that there were significant differences between 
genotypes at all three ages $\left(\mathrm{F}_{8.303}=13.2 ; \mathrm{F}_{8,283}=8 \cdot 2 ; \mathrm{F}_{8,292}=13.6 ;\right.$ all $\left.P<0.001\right)$, and these are shown in Table 1.

The mean weights of the paired testes of the 10 genotypes of mice are also given in Table 1 . At all three ages mice of the $\mathrm{C} 57 \mathrm{BL} / 10 \mathrm{ScSn}$ strain had testes that were larger than those of the $\mathrm{C} 57 \mathrm{BL} / 6 \mathrm{By}$ mice but lighter than those of the BALB/cBy males. In both $\mathrm{C} 57 \mathrm{BL}$ substrains absolute testis weight increased very little between the ages of 60 and 120 days. In contrast, over the same age period testicular weight increased by three times as much in the BALB mice even though their bodyweight increased at only half the rate found in the C57BL mice.

Analysis of variance carried out at each of the three ages showed highly significant differences $\left(\mathrm{F}_{8,303}=27 ; \mathrm{F}_{8,283}=85 ; \mathrm{F}_{8,292}=134 ;\right.$ all $\left.P \ll 0 \cdot 001\right)$. At 30 days of age the mean values for mice of the seven RI lines fell into two groups: mice of one group, comprising the CXBD and CXBH RI lines, had large testes like mice of the BALB strain, whilst mice in the other group, of five RI lines, had testes smaller than those of mice of the C57BL/10ScSn strain. The rank orders of the stocks at 60 and 120 days were highly correlated $\left(r_{\mathrm{s}}=0.98, P<0.001\right)$, whereas the correlation between mean testis weights at 30 and 60 days was only $0.68(P>0.01)$. When adult, none of the mice in the $\mathrm{RI}$ lines had a mean testis weight as low as that of their $\mathrm{C} 57 \mathrm{BL} / 6 \mathrm{By}$ progenitor while CXBD mice were very similar to mice of their BALB/cBy progenitor strain and $\mathrm{CXBH}$ adults had significantly larger testes.

At all three ages $\mathrm{C} 57 \mathrm{BL} / 6 \mathrm{By}$ mice had significantly smaller seminiferous tubules than did BALB $/$ cBy males $\left(F_{1.154}=54, \quad P<0.001\right)$. Their cross-sectional area was $15.8 \pm 0.6$ $\left(\mathrm{mm}^{2} \times 10^{-3}\right)$ in C57BL/6By mice and $20 \cdot 1 \pm 0 \cdot 8\left(\mathrm{~mm}^{2} \times 10^{-3}\right)$ in BALB/cBy at 30 days of age. Mean tubule area $\left(\mathrm{mm}^{2} \times 10^{-3}\right)$ increased between the ages of 60 and 120 days in BALB/cBy mice, from $25 \cdot 0 \pm 1 \cdot 1$ to $30 \cdot 7 \pm 1 \cdot 1$, but not in C57BL/6By mice $(21 \cdot 8 \pm 0.8$ and $21.6 \pm 0.9)$, paralleling changes in testicular weight.

\section{Discussion}

Throughout the age range studied $\mathrm{C} 57 \mathrm{BL} / 6 \mathrm{By}$ mice had consistently smaller testes than did $\mathrm{BALB} / \mathrm{cBy}$ mice. The strain difference in absolute testis weight increased from $27 \%$ at 30 days to $41 \%$ at 60 days and $44 \%$ at 120 days. In contrast, the bodyweights of C57BL/6By mice were only $15 \%$ and $2 \%$ smaller than those of BALB/6By mice at 30 and 60 days and were $10 \%$ larger at 120 days. The absolute weight of the testes did not increase between the ages of 60 and 120 days in either of the C57BL sublines but testicular growth continued in the BALB males. The crosssectional area of the seminiferous tubules showed the same pattern. Thus the C57BL/6By mice are unlike the CBA/FaCam mice in which seminiferous tubule diameter was not affected, even though their testes weighed only $100 \mathrm{mg}$ (Hayward \& Shire, 1974; Stewart, 1983).

Mean testicular weight increased between 60 and 120 days in mice of all seven RI lines, and the rankings of the RI lines were very similar at these two ages. None of the RI lines had mice with testes as small as those of C57BL/6By mice. Some RI lines had intermediate phenotypes and the phenotype of one, CXBJ, closely resembled that of the BALB progenitor strain. Mice of other RI strains, notably $\mathrm{CXBH}$, had testes that were significantly larger than those of mice of either of their progenitor strains, even though the growth curve for bodyweight of the CXBH mice closely resembled that for the BALB mice. The existence of such a range of recombinant phenotypes, including ones more extreme than one progenitor, together with the absence of a strain with a phenotype like that of the other progenitor strain, implies that multiple factors control the difference between the strains. A similar pattern, in which the phenotype of the BALB progenitor but not that of the C57BL progenitor was recovered in the RI lines, was found for variation in the epithelial structure of the seminal vesicles, which was relatively unorganized and dysplastic in C57BL/6By mice (Shukri et al., 1988). All the CXB RI lines have the C57BL/6By Y chromosome and so the differences amongst them do not reflect variation in Y-linked loci. Such Y-linked loci have been 


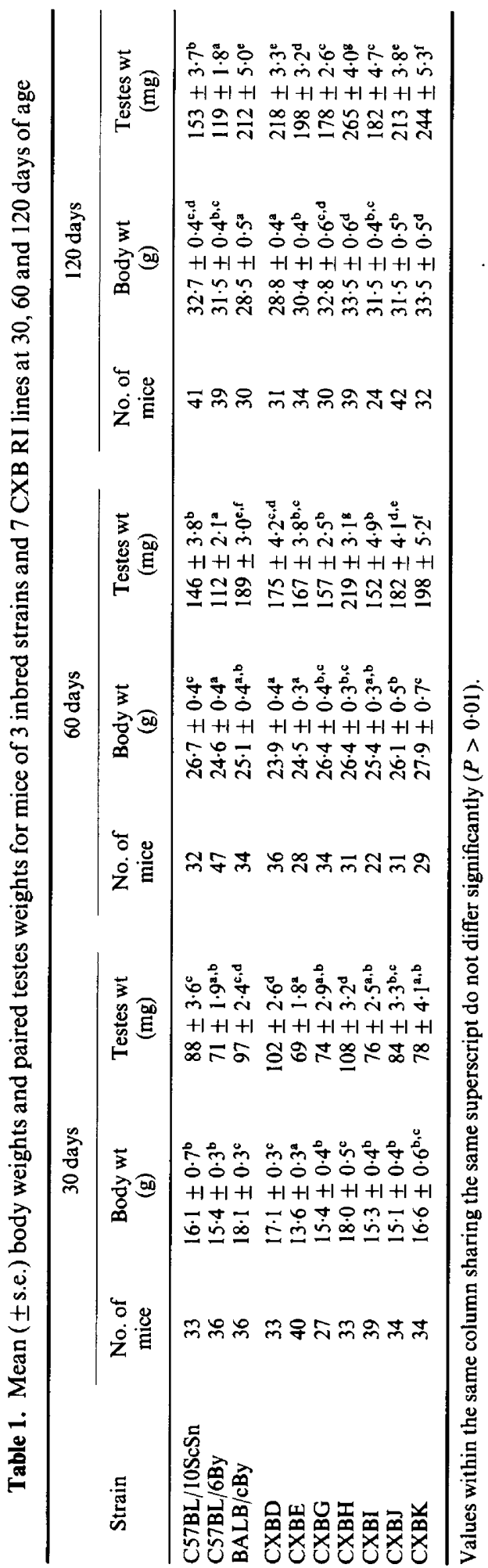


shown to affect testicular weight in CBA/FaCam (Hayward \& Shire, 1974; Stewart et al., 1980), CBA/Gr (Hunt \& Mittwoch, 1987), PHH (Stewart, 1983) and DBA/2J (Herrick \& Wolfe, 1977) mice.

At 30 days of age testicular weight showed a very different pattern of phenotypic variation. The phenotypes of mice of the RI lines fell into two groups: mice of five RI lines had small testes like C57BL/6By mice and mice of two RI lines, CXBD and $\mathrm{CXBH}$, had large testes like mice of the BALB progenitor strain. The pattern is that expected if variation in testicular weight at this age is controlled by a single locus. The pattern found for the RI lines matches exactly the segregation at the $\mathrm{H}-2$ histocompatibility locus. CXBD and $\mathrm{CXBH}$ mice are both homozygous for the $\mathrm{H}-2^{\mathrm{d}}$ allele contributed by the BALB mice while the other five RI lines are homozygous for the $H-2^{\mathrm{b}}$ allele, derived from the $\mathrm{C} 57 \mathrm{BL} / 6 \mathrm{By}$ progenitor. This suggests that a gene differing between the two progenitor strains is located in the part of chromosome 17 marked by the $H-2$ complex. A similar overall pattern of phenotypes was found for bodyweight at 30 days (Table 1). All the $H-2^{d}$ strains had larger bodyweights and lower growth velocities than did the six $H-2^{\text {b }}$ strains, suggesting that the critical locus may affect general growth characteristics even though the strain difference in testicular weight $(26 \mathrm{mg})$ was proportionately greater than that in bodyweight. A small effect of $\mathrm{H}-2$ haplotype on the absolute testicular weight of adult mice has been described by Gregorova et al. (1977). They found that the testes of 80-90-day-old A/Ph mice weighed $11 \mathrm{mg}$ more than those of $\mathrm{C} 57 \mathrm{BL} / 10 \mathrm{ScSnPh}$ mice and reported a significant difference of $12 \mathrm{mg}$ between the testicular weight of $H-2^{\mathrm{a}}$ and $H-2^{\mathrm{b}}$ homozygotes in an $\mathrm{A} \times \mathrm{C} 57 \mathrm{BL} /$ $10 \mathrm{~F} 2$ cross.

It is clear that different genes are being expressed prepubertally and in the adult. Argyropoulos \& Shire (1989) have shown that prenatally, at 18 days of gestation, the testes of C57BL/6By mice are significantly larger than those of $\mathrm{BALB} / \mathrm{cBy}$ mice. At 15 days of gestation they were significantly smaller than those of BALB mice. The testes of the CXBD and CXBD RI mice were the same size as those of $\mathrm{C} 57 \mathrm{BL} / 6 \mathrm{By}$ on the 18 th day of gestation even though they fell into different phenotypic classes 30 days after birth. Thus the direction of the strain difference found reverses during fetal and postnatal life. Stewart (1983) found a similar change during development for the pattern of differences between $\mathrm{Y}$-chromosome substitution lines, with mice with a CBA/FaCam $\mathrm{Y}$-chromosome having larger testes than mice with a C57BL/6Fa Y-chromosome before birth but smaller ones after birth. Such changes during development contrast with the constant direction of the difference in testicular size prenatally and postnatally when BALB/cOla and CBA/Gr were compared (Hunt \& Mittwoch, 1987). It also contrasts with the findings of Land \& Carr (1979) and Knight (1984) that differences in the neonatal size of the testes between breeds of sheep correlated well with, and predicted, adult reproductive performance in both sexes.

The mean testicular weight found for BALB/cBy males was very similar to that found for the BALB/cJ (Shire \& Bartke, 1972; West et al., 1980; Dott et al., 1983) and BALB/Gr (Hunt \& Mittwoch, 1987) sublines. In contrast C57BL sublines have different sized testes. This is so even when comparisons are made within the major divisions of the strain, represented by the separate inbreeding of the 6 and 10 sets of sublines since 1935 (Bailey, 1978). Mice of the 6J subline had relatively large testes (Shire \& Bartke, 1972; Eleftheriou \& Lucas, 1974; Stewart et al., 1980; West et al., 1980; Stalvey \& Payne, 1983) as did those of the Tb subline (J. G. M. Shire, unpublished observations), while males of the 6By subline have testes weighing only $112 \mathrm{mg}$ (and $106 \mathrm{mg}$ in an independent set of measurements made earlier on mice aged 58 days). In the 10 series of sublines, mice of the $10 \mathrm{ScSn}$ sublines have an intermediate testicular weight of around $150 \mathrm{mg}$ (this paper; Gregorova et al., 1977) while testicular weight declined in the $10 \mathrm{~J}$ subline from an intermediate value at 60 days (Shire \& Bartke, 1972) to around $100 \mathrm{mg}$ by 80 days (Shire $\&$ Bartke, 1972; West $e t$ al., 1980; Stalvey \& Payne, 1983). The endocrine factors involved in these differences remain to be elucidated.

We thank Sheila Bareham and David Spayne for skilled animal husbandry. 


\section{References}

Argyropoulos, G. \& Shire, J.G.M. (1989) Genotypic effects on gonadal size in fetal mice. $J$. Reprod Fert. 86, 473-478.

Bailey, D.W. (1971) Recombinant inbred strains: An aid to finding identity, linkage and function of histocompatibility and other genes. Transplantation 11, 325-327.

Bailey, D.W. (1978) Sources of subline divergence and their relative importance for sublines of six major inbred strains. In Origins of Inbred Mice, pp. 197-215. Ed. H. C. Morse. Academic Press, New York.

Bander, S.A.A., Watson, S.C. \& Shire, J.G.M. (1988) Genetic differences in periovum sensitivity to hyaluronidase and protease between C57BL/6, BALB and CXB recombinant mice. J. Reprod. Fert. 84, 709-714.

Bartke, A. (1974) Increased sensitivity of seminal vesicles to testosterone in a mouse strain with low plasma testosterone levels. $J$. Endocr. 60, 145-148.

Bartke, A. (1979) Genetic models in the study of anterior pituitary hormones. In Genetic Variation in Hormone Systems, Vol. 1, pp. 113-126. Ed. J. G. M. Shire. CRC Press, Boca Raton.

Batty, J. (1978) Plasma levels of testosterone and male sexual behavior in strains of the house mouse ( $\mathrm{Mus}$ musculus). Anim. Behav. 26, 339-348.

Diamond, J.M. (1986) Variation in human testis size. Nature, Lond. 230, 488-489.

Dott, H.M., Dore, C.J., Foster, G.C.A., Halsey, M.J., Monk, S., Sechell, B.P. \& Wardley-Smith, B. (1983) Effect of exposure to high environmental pressure on spermatogenesis in mice. Gamet. Res. 8, 87-94.

Eleftheriou, B.E. \& Kristal, M.B. (1974) A gene controlling bell- and photically-induced ovulation in mice. J. Reprod. Fert. 38, 41- 47.

Eleftheriou, B.E. \& Lucas, L.A. (1974) Age-related changes in testes, seminal vesicles and plasma testosterone levels in male mice. Gerontologia 20, 23 I-238.

Fahle, M. \& Palm, G. (1983) Calculation of surface areas from serial sections. J. Neurosci. Meth. 9, 75-85.

Festing, M.F.W. (1979) Inbred Strains in Biomedical Research. Macmillan Press Ltd, London.

Gregorova, S., Ivanyi, P., Simonova, D. \& Mickova, M. (1977) H-2 associated differences in androgeninfluenced organ weights of $A$ and $C 57 \mathrm{BL} / 10$ mouse strains and their crosses. Immunogenetics 4, 301-313.

Hayward, P. \& Shire, J.G.M. (1974) Y chromosome effect on adult testis size. Nature, Lond. 250, 499-500.

Herrick, C.S. \& Wolfe, H.G. (1977) Effect of the Y chromosome on testis size in the mouse (Mus musculus). Genetics, Princeton 86, s 27 abstr.

Hunt, S.E. \& Mittwoch, U. (1987) Y-chromosomal and other factors in the development of testis size in mice. Genet. Res. 50, 205-211.

Islam, A.B.M., Hill, W.G. \& Land, R.B. (1976) Ovulation rates of lines of mice selected for testis weight. Genet. Res. 27, 23-32.

Knight, T.W. (1984) Testicular growth and size in rams from flocks with different reproductive potential. N. Z. J. agric. Res. 27, 179-188.
Land, R.B. \& Carr, W.R. (1979) Reproduction in domestic mammals. In Genetic Variations in Hormone Systems, Vol. 1, pp. 89-112. Ed. J. G. M. Shire. CRC Press, Boca Raton.

Maxson, S.C. (1981) The genetics of aggression in vertebrates. In The Biology of Aggression, pp. 69-104. Eds P. F. Brain \& D. Benton. Sythoff \& Noordhoff International Publishers, Amsterdam.

Nie, N.H., Hull, C.H., Jenkins, J.G., Steinbrenner, K. \& Bent, D.H. (1975) Statistical Package for the Social Sciences, 2nd edn. McGraw-Hill, New York.

Osadchuk, A.V. \& Naumenko, E.V. (1983) Geneticoendocrine and ethologic mechanisms of differential reproduction. I. Comparative genetic analysis of the basal plasma testosterone level, relative weight of the testicles and accessory sex glands in laboratory male mice. Genetika 19, 1265-1272.

Paigen, K. (1978) Genetic control of enzyme activity. In Origins of Inbred Mice, pp. 255-278. Ed. H. C. Morse. Academic Press, New York.

Shire, J.G.M. (1981) Genes and hormones in mice. Symp. zool. Soc. Lond. 47, 547-574.

Shire, J.G.M. (1984) Studies on the inheritance of vaginal septa in mice, a trait with low penetrance. $J$. Reprod. Fert. 70, 333-339.

Shire, J.G.M. \& Bartke, A. (1972) Strain differences in testicular weight and spermatogenesis with special reference to C57BL/10J and DBA/2J mice. $J$. Endocr. 55, $163-171$.

Shire, J.G.M. \& Whitten, W.G. (1980) Genetic variation in the timing of first cleavage in mice: effect of maternal genotype. Biol. Reprod. 23, 369-376.

Shukri, N.M., Grew, F. \& Shire, J.G.M. (1988) Recessive mutation in a standard recombinant-inbred line of mice affects seminal vesicle shape. Genet. Res. 52, 27-32.

Stalvey, J.R.D. \& Payne, A.H. (1983) Luteinizing hormone receptors and testosterone production in whole testes and purified Leydig cells from the mouse: differences among inbred strains. Endocrinology 112, 1696-1701.

Stewart, A.D. (1983) The role of the Y-chromosome in mammalian sexual differentiation. In Development in Mammals, Vol. 5, pp. 321-367. Ed. M. H. Johnson. Elsevier Science Publishers, Amsterdam.

Stewart, A.D., Manning, A. \& Batty, J. (1980) Effects of $Y$-chromosome variants on the male behaviour of the mouse Mus musculus. Genet. Res. 35, 261-268.

West, W.T., Evans, M.I. \& Hamilton, J.B. (1980) Strain differences in target organ weight changes among mice treated with androgens. Growth 44, 36-45.

Wiebe, J.P. (1976) Steroidogenesis in rat Leydig cells: changes in activity of 5 -ane and 5-ene $3 \beta$-hydroxysteroid dehydrogenase during sexual development. Endocrinology 98, 505-513.

Wolfe, M.G., Bartke, A., Amador, A.G., Van Sickle, M., Dalterio, S. \& Brown, D. (1981) Testicular function in strains of mice selected for differences in gonadotrophin-induced ovulation rate. J. Endocr. 90 , $367-373$.

Received 23 February 1989 